\title{
The European Energy Divide
}

\begin{abstract}
This chapter reviews the spatial and social differences that underpin existing and past patterns of energy poverty in Europe. This is achieved via exploration of scientific research focused on the topic, either as a central object of enquiry or as part of wider investigations in which the issue is brought up as a relevant factor. Special attention is paid to the large-scale geographic variation of energy poverty in Europe, as well as the manner in which this diversity is subsequently reflected at the level of nations, regions and particular demographic groups. I also discuss the driving forces of energy poverty within particular spatial contexts; and in an effort to move beyond the traditional geographic focus of energy poverty research-the UK and Ireland-the chapter first systematically overviews the development of a debate focusing on different parts of the European continent and its immediate neighbourhood. I then review evidence about patterns of energy poverty at a variety of spatial scales.
\end{abstract}

Keywords Energy poverty $\bullet$ Energy vulnerability $\bullet$ Material deprivation - Uneven development • Europe 


\section{INTRODUCTION}

As was noted earlier in the book, the majority of evidence about the underlying causes of energy poverty has been generated by studies undertaken in the UK and the Republic of Ireland (RoI). Academic research on 'fuel poverty' produced in these two states has uncovered that the condition is brought about, in the main, by the interaction of low household incomes with thermally inefficient homes (Boardman, 2010). It has been underlined that the residents of inefficient dwellings are forced to purchase less affordable energy services than the rest of the population, because such homes are more expensive to heat. In relative terms, energy services are also less affordable to income-poor households, since such families will have lower amounts of disposable funds for such purposes. But the fact that fuel poverty is co-produced by energy efficiency and low incomes means that not all income-poor households will also be fuel poor. Additionally, the extensive nature of fuel poverty in the UK and RoI-itself a product of the two countries' specific inequality patterns and housing stock structure-has allowed for an additional range of factors relevant to the rise of fuel poverty to be identified by researchers. This has included patterns of housing tenure, the nature of heating systems as well as socio-demographic circumstances such as household size, gender, class or education.

Scientists exploring the contingencies of energy poverty in the UK and RoI have often emphasized the deleterious health consequences of living in inadequately heated homes and the relationship between domestic energy deprivation and thermal efficiency interventions (Liddell \& Morris, 2010). It has also been highlighted that energy poverty decreases the quality of life and influences social attainment. Authors working in this vein have argued that 'raising incomes can lift a household out of poverty, but rarely out of fuel poverty' (Boardman, 1991, p. xv), since residential energy inefficiency is the main reason for fuel poverty, and low-income households have to buy expensive warmth. Some researchers have pointed out that the spatial distribution of fuel poverty is highly sensitive to the way in which household incomes are measured. They have claimed that, regardless of the operational definition and measurement approach, households that need to spend more than 10 per cent of their income on energy on heating are generally not the same households as those in fact reporting difficulty in doing so.

As is argued in the sections that follow, such measurement and detection difficulties also apply to the wider European context. This chapter, 
therefore, first traces the evolution of work on energy poverty across Europe before reviewing the distribution and composition of energy-poor populations.

\section{Energy Poverty in Continental Europe: Multi-sited Studies}

The amount and depth of energy poverty-relevant research decrease rapidly once the focus is shifted away from the British Isles and onto continental Europe. Nevertheless, the generic causes of domestic energy deprivation in this context can be inferred from the emergent body of work pertaining to the European Union (EU) Member States and their neighbours. Similar to the UK and RoI, these arguments accepted that energy poverty in continental European countries arises out of a combination of low incomes and inefficient homes. However, it became increasingly recognized that the specific energy needs of a household-expressed via demographic circumstances such as household size, gender, occupation or class - also play a role. Of no less significance is the nature of housing tenure and heating system, since they may limit the energy efficiency interventions and fuel switching measures that can reduce energy costs (Bouzarovski \& Simcock, 2017; European Commission, 2013; Pye et al., 2015).

Some of the initial non-UK and non-RoI scholarship about the energy and poverty nexus in multiple European countries included analyses of housing, fuel poverty and health in the European context, using data from the European Community Household Panel (ECHP). Contributions in this vein were based on a consensual approach, which 'unlike traditional forms of measuring relative poverty ... does not rely on the opinions or scientific postulates of academics or experts' (Healy, 2017, p. xii). They combined objective housing data with 'indicators of socially perceived necessities' to demonstrate, inter alia, the central role of inefficient homes and poorly designed-or absent-heating systems in the production of energy poverty. Of note was a 14-country exploration of excess winter mortality: describing a seasonal increase in deaths that can be commonly attributed to 'cold strain from both indoors and outdoors' (Healy, 2003, p. 784). It linked information about thermal efficiency standards and mortality patterns with 'longitudinal datasets on risk factors pertaining to climate, macroeconomy, health care, lifestyle, socioeconomics, and housing' (ibid.). 
The results of this investigation established that 'those countries with the poorest housing (Portugal, Greece, Ireland, the UK) demonstrate the highest excess winter mortality' (Healy, 2003, p. 788); socio-economic well-being was also shown to play a role.

Also influencing early energy poverty debates was World Health Organization-led investigation of 'housing, energy and thermal comfort' in eight European countries, plus Kazakhstan and Kyrgyzstan. Using a range of independently gathered data, many of the country case studies within this inquiry established that seasonal winter mortality was a problem across Europe. Its conclusions underlined that 'inadequate housing' is the fundamental problem in this context. The authors also argued against a pan-European definition of 'fuel poverty', emphasizing that it may be 'more appropriate to give guidance on the factors to be taken into account in developing a national definition' (World Health Organization Regional Office for Europe, 2007, p. 10).

Among the most widely cited pieces of research in this domain are the results of the aforementioned EPEE (European Fuel Poverty and Energy Efficiency) project, which used three indicators from the SILC (Statistics on Income and Living Conditions) data set ('ability to pay to keep one's home adequately warm', 'leaking roofs, damp walls/floors/foundation, or rot on window frames/floors', 'arrears on utility bills') to evaluate the extent of fuel poverty in Belgium, Spain, France, Italy and the UK. This data was then cross-referenced with information from other demographic indicators in SILC, as well as national surveys about the level of household incomes, as well as the nature of the housing stock and heating system. The study emphasized that one in seven households in Europe is in or at the margins of 'fuel poverty', locating the causes of the condition within the familiar context of low household incomes, insufficient heating and insulation standards and high energy prices.

Moving further east, the World Bank also sponsored an investigation of heating strategies among the urban poor in Croatia, Latvia, Lithuania, Moldova as well as Armenia, Kyrgyzstan and Tajikistan (Lampietti \& Meyer, 2002). Even though this inquiry did not use an explicit 'energy poverty' lexicon, it did offer a broad-level investigation of household energy consumption and heating patterns in the selected countries. Having illuminated the wider relationship among heating, poverty alleviation and environmental quality issues, the research provided a series of policy suggestions about the necessary steps to design policies that will enable the 
provision of 'clean heat' in 'fiscally sustainable ways' (Lampietti \& Meyer, 2002 , p. 23). The study built on previous World Bank-led work in the region (Buckley \& Gurenko, 1997; World Bank, 1999a, b).

Working along similar lines but with a stronger focus on social policy issues was an exploration of the social safety nets for energy price increases used by Bulgaria and Romania, in addition to Armenia and Kazakhstan (Velody, Cain, \& Philips, 2003). Having established that 'energy costs are the highest monthly expense after food for most low-income households in the region' (Velody et al., 2003, p. vii), the study examined the poverty alleviation role played by three types of mechanisms: fuel assistance payments, energy efficiency improvements in low-income residences and 'progressive' tariff structures. It concluded that social protection instruments at the energy-poverty nexus were most effective if they provided a well-targeted and meaningful level of assistance, and were implemented via stand-alone and easily manageable mechanisms. The results of this work were echoed in a report on power sector affordability in South East Europe, which, having undertaken a series of analyses, found that many South East European countries have not yet developed adequate social safety mechanisms to protect energy-poor consumers (European Bank for Reconstruction and Development, 2003, p. 2).

There is also research that operates at a broader geographical scale, but in more narrow conceptual terms. A working paper published by the European Bank for Reconstruction and Development examined how 'energy burdens' (the share of household income devoted to energy) would change across 27 post-socialist countries in Eastern and Central Europe (ECE) and the Former Soviet Union (FSU) in a situation where 'all utility prices are raised steadily to reach full cost recovery levels by 2007' (Fankhauser \& Tepic, 2007, p. 15). Having noted that 'it is surprising how little we still know about the consumption patterns and well being of low income households' (ibid.), its authors claimed that 'delaying tariff adjustments may not be an effective way of mitigating the social impact of tariff reform' (Fankhauser \& Tepic, 2007, p. 15).

In their entirety, such studies confirm that one of the key driving forces of energy poverty in the Eastern European context have been energy price increases undertaken after the fall of communism, so as to bring electricity and gas tariffs-formerly subject to indirect subsidies by the state-up to cost-recovery levels. Work in ECE and FSU has thus revealed a series of 'pervasive geographies' of energy poverty arising from the failure of the 
state to respond to price increases with adequate social welfare support and energy efficiency investment (Buzar, 2007b). Other key driving factors include tenure patterns within the housing stock, as well as the regulation of energy markets; more recently a further complication has been added by the effects of the financial crisis and associated mortgage payments (Maxim, Mihai, Apostoaie, \& Maxim, 2017). Nevertheless, a lack of unified approaches has been noted, in addition to the disproportionate coverage of energy poverty within social policy.

Much of this work has highlighted the significant difficulties faced by disadvantaged households in the region. It has demonstrated that, in addition to affordability and energy efficiency issues, important dimensions in the rise of energy poverty include the nature of household energy needs, as well as the fact that some demographic groups are 'trapped' in housing arrangements and heating systems that do not allow for switching towards less expensive and more comfortable ways of providing energy services (Buzar, 2007c; Tirado Herrero \& Urge-Vorsatz, 2012). Research focusing on the relationship between a household's awareness of climate change issues, on one hand, and energy efficiency retrofits, on the other, has also provided a range of energy poverty-relevant insights (Bouzarovski, 2015). It has highlighted that the poor quality of the housing stock may combine with the feeling of being too cold, hot or uncomfortable in driving energyrelated renovations in privately owned dwellings (Bartiaux et al., 2012; Cirman, Mandič, \& Zorić, 2013).

Energy poverty-relevant evidence can also be found in a study of 'the effects of energy reforms on the probability of households experiencing deprivation, defined as difficulty in paying the bills' (Rezessy, Dimitrov, Ürge-Vorsatz, \& Baruch, 2006, p. 253). Authors working in this vein provide a range of statistical analyses of ECHP and SILC data for Denmark, Belgium, France, Ireland, Italy, the Netherlands, Spain, Austria, Finland, Luxembourg, Norway and Sweden. Their conclusions highlight that 'unbundling vertically integrated activities in the electricity sector and reducing public ownership in the gas sector are both correlated with higher probability of experiencing deprivation' (Rezessy et al., 2006, p. 262). Academics have also used statistical analyses of SILC and European Quality of Life Survey data to explore the relationship between selfreported energy poverty-relevant indicators and other socio-demographic and spatial variables (Thomson \& Snell, 2013; Thomson, Snell, \& Bouzarovski, 2017). 


\section{In-Depth Research at the National and Local Scale}

Research relevant to the causes and consequences of domestic energy deprivation has also been produced in relation to the circumstances of particular countries. One of the most influential debates in this regard commenced with a highly publicized paper on the welfare effects of raising household energy prices in Poland (Freund \& Wallich, 1996). Its empirical analysis was based on data from the 1993 Polish household budget survey, 'which contains information on the expenditures of 16,044 Polish households, surveyed between January and June 1993' (Freund \& Wallich, 1996, p. 55). Examining the expenditure patterns of households in five equivalent income quintiles led the authors to conclude that 'not only did the better off spend a larger absolute amount on energy than the poor, they also consumed a larger proportion of their expenditures as energy' (ibid.). A similar analytical approach was used in research of the extent to which 'electricity tariff increases in Ukraine hurt the poor' (Dodonov, Opitz, \& Pfaffenberger, 2004, p. 855), whose authors recommended that price increases up to levels comparable to those in OECD (Organisation for Economic Cooperation and Development) countries 'should only be realized in steps' (ibid.).

The results of these studies have been favourably received in policy circles; the fact that their findings chimed in with the neoliberal agenda for energy sector unbundling and privatization pursued throughout Europeand particularly in the East-after 1989 has allowed them to be widely cited in the literature on energy sector reform even though the use of elasticities and consumer surplus to estimate social welfare in conditions of 'very high price increases' has been problematized by some (Bacon, 1994). Many policy discussions of the distributional consequences of energy restructuring have widely cited the finding that implicit energy price subsidies benefit the 'rich' more than the 'poor' (Buzar, 2007a).

Also focused on issues of energy affordability as they relate to price increases is an investigation of the distributional effects of regulatory reforms in the Italian water and energy utility sectors (Miniaci, Scarpa, \& Valbonesi, 2008). Using a range of regional, demographic and climatic indicators, its authors have constructed an affordability index for public utility consumption, so as to overcome the absence of an official energy poverty definition in Italy. Their findings, which are based on statistical modelling of large data sets from the Italian family budget survey, indicate that in the period considered, reforms in the water, natural gas and 
electricity markets were not accompanied by exacerbated affordability issues in Italy' (Miniaci et al., 2008, p. 162). More recent work has updated and developed these findings further, by exploring the wider context of network industry reform, as well as the role of regional policies (Florio, 2013; Scarpellini, Sanz Hernández, Llera-Sastresa, Aranda, \& López Rodríguez, 2017).

There have also been several multinational organization-led studies using an explicit energy poverty framework in the design of research methods and approaches. A United Nations Development Programmesupported investigation in Serbia and Montenegro provided an integrated and comprehensive take on the relationship between energy, poverty and environmental problems. It introduced access considerations to the equation, by distinguishing between indicators relevant to the provision of energy services-including fuel consumption and the use of household energy appliances-and measures of the sufficiency of energy services, such as space heating, ventilation, domestic hot water and cooking (Kovačević, 2004).

Other ECE states have also been the subject of scientific attention in the field of domestic energy deprivation. The expansion of energy poverty in Bulgaria has been documented using interview and national household survey data, and with reference to EU and national policies. Part of the context for such work stems from the fact that in addition to having some of the highest rates of households reporting inadequate domestic thermal comfort in the SILC survey, this country has also implemented extensive energy privatization and liberalization reforms during the past 15 years (Bouzarovski, Petrova, \& Sarlamanov, 2012; Lenz \& Grgurev, 2017). Energy poverty in Poland has also been extensively studied and described thanks to the work of the Institute of Structural Research as well as several academic researchers (Miazga \& Owczarek, 2015).

As we argued in a recent co-authored paper (Bouzarovski, Tirado Herrero, Petrova, \& Ürge-Vorsatz, 2016), successive Hungarian governments have been making various attempts to buffer the impact of growing energy prices on the purchasing power of Hungarian households and voters. These politically motivated policy interventions have mainly taken the form of regulated energy prices and relatively short-lived subsidy schemes. Utility cuts are firmly entangled in political strategies to gain electoral support by confronting EU institutions and international corporations. Presented as the 'battle of the utility bills' (rezsiharc), such efforts were a central theme of the right-wing government's 
campaign before the April 2014 general elections, in which the populist Fidész party achieved a new parliamentary majority. While it is likely that the measures have brought short-term benefits to low-income households by allowing for a reduction in energy burdens, their ability to address the wider spatial and infrastructural components of energy poverty and vulnerability is questionable. This is because they have preferentially supported urban consumers of natural gas and district heating, while failing to provide relief to households (mostly in rural areas) relying on bottled natural gas or firewood as a source of heat (Szivós, Bernát, \& Köszeghy, 2011). Also, there have been fears that the subsidies may increase rates of energy poverty by diverting resources that could be used for reducing the country's supply dependency on Russia, or investing in residential energy efficiency.

Significant forays are also being made into scientific understandings of the underlying causes of energy poverty in various Southern European countries, where the condition has received almost no academic attention to date. This includes insights into the causes and patterns of energy poverty in Spain (Phimister, Vera-Toscano, \& Roberts, 2015; SánchezGuevara Sánchez, Mavrogianni, \& Neila González, 2017; Tirado \& Jiménez Meneses, 2016); such work has demonstrated the existence of a close link between unemployment and energy poverty, in addition to establishing that existing social safety nets are failing to provide adequate assistance to energy-poor populations. An extensive study in the Greek capital Athens has uncovered the links between low incomes and energy efficiency by establishing that 'low income people are more likely to be living in old buildings with poor envelope conditions' (Santamouris et al., 2007 , p. 893). Operating on a vastly different-but no less relevantscale, research of energy-saving interventions in this country's mountainous areas has led the author to conclude that 'utilizing locally produced biomass and applying energy-saving measures can bring households below the energy poverty limit' (Katsoulakos, 2011, p. 284). The geographies of energy poverty in Greece and Cyprus are now among the most studied in Europe (Atsalis, Mirasgedis, Tourkolias, \& Diakoulaki, 2016; Boemi, Avdimiotis, \& Papadopoulos, 2017; Boemi \& Papadopoulos, 2017; Katsoulakos \& Kaliampakos, 2016; Papada \& Kaliampakos, 2017; Petrova, 2017; Santamouris et al., 2014), and work by Greek researchers has also contributed to an improved understanding of indoor conditions across Europe (Kolokotsa \& Santamouris, 2015). 
Western European countries have also attracted significant new interest. An exploration of the everyday strategies that are employed by Austrian households in order to alleviate domestic energy deprivation has revealed that 'energy-inefficient windows, buildings and housing sites are the cause of heavy burdens' (Brunner, Spitzer, \& Christanell, 2012, p. 7) for this group. Conceptualizing processes of targeting, identification of households and implementation as three interdependent steps has highlighted the complex errors of inclusion and exclusion implicated in the design of France's rapidly developing fuel poverty policy (Dubois, 2012). The increasing amount of public attention and state funding attracted by the energy poverty predicament in this country has been accompanied by the expansion of scientific research devoted to the issue, especially in terms of the relationship between vulnerability patterns and support policies (Bafoil, Fodor, \& le Roux, 2014; Bartl, 2010; Legendre \& Ricci, 2015; Ortar, 2016). Several recent contributions indicate that energy poverty is even present in countries like Germany, where rates of social inequality and inefficient housing are at record low levels (Becker, Kouschil, \& Naumann, 2014; Billen, 2008; Großmann, Schaffrin, \& Smigiel, 2016; Kopatz, 2009; März, 2017; Tews, 2014).

\section{Geographic Patterns of Energy Poverty in Europe}

I now turn to the social and spatial patterns of domestic energy deprivation across Europe, which, as evidenced by some of the work reviewed above, are highly geographically variable and locally contingent. General insights about the geographic extent of energy poverty in the EU can be gleaned from published SILC data. Based on the consensual approach (Healy, 2017) the information generated by the subjective measure on 'inability to keep the home warm' can be combined with more objective data about the shares of each country's population facing disproportionately high housing burdens, living in low-quality dwellings or having arrears on utility bills. Dividing each of these objective indicators by 3 (as they do not necessarily demonstrate energy poverty themselves), and adding them to the more direct subjective measure referring to the level of domestic heating, offers broad information about Europe's spatial patterns of energy poverty (Fig. 4.1).

The highest shares of populations with insufficient self-reported domestic warmth are concentrated in the part of the EU that is constituted by the post-socialist states of ECE (also referred to as the EU-10), especially 


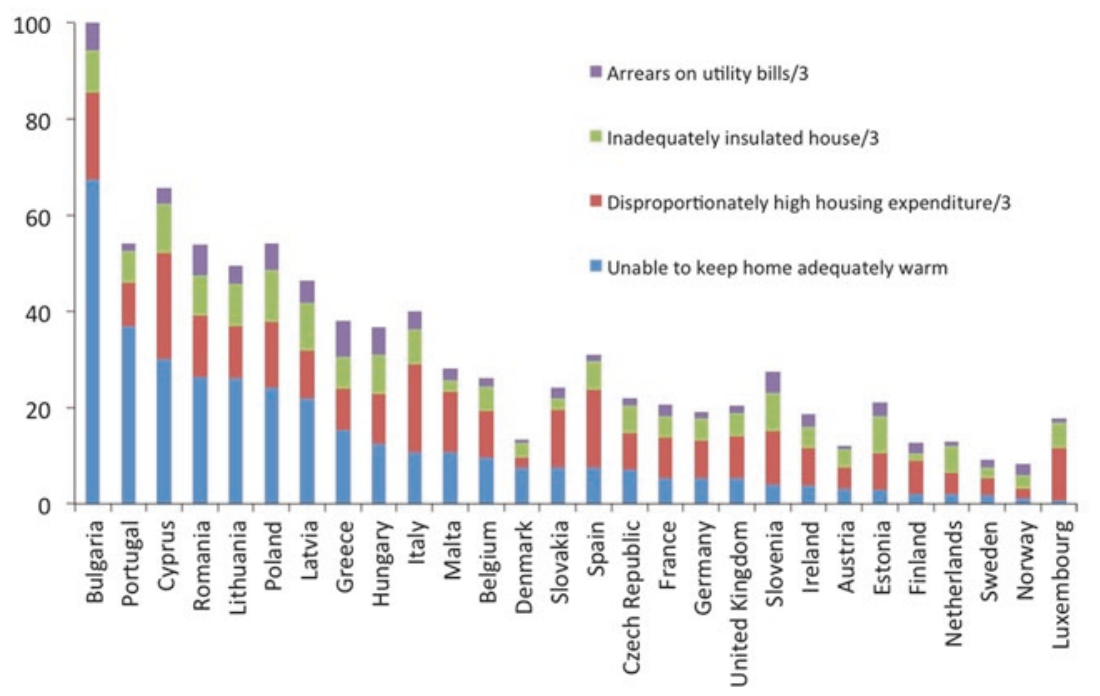

Fig. 4.1 A composite fuel poverty indicator based on the shares of populations in different EU countries facing selected energy poverty-related problems, with the values of the three 'objective' measures divided by 3 . Originally published in Bouzarovski (2014)

Bulgaria. In such countries, the share of the population reporting inadequately heated homes has been 20.0 per cent, while the value of the composite fuel poverty indicator is 44.5 per cent. This is against EU-wide averages of 12.8 and 31.7 per cent, respectively. Also scoring high according to the same criteria are the eight EU countries that border the Mediterranean Sea, where 16.6 per cent of the population has reported being 'unable to keep their home adequately warm', while the composite fuel poverty indicator reaches 43.58 per cent.

As we argued in Bouzarovski and Tirado Herrero (2017b) existing knowledge thus suggests a macro-regionalization of the EU in several clusters of countries with different energy poverty levels and dynamics. In order to explore the consistency of this categorization with respect to correlation analysis presented in the previous section, we plotted the average value of Eurostat's monetary deprivation indicator 'at-risk-of-poverty' rate (percentage of the population with an income below 60 per cent of the national median, after social transfers) against an ad hoc composite energy 
poverty index for each member state. The energy poverty index took into account the SILC population percentages of people who have reported (i) being unable to keep their homes adequately warm (Inability); (ii) having arrears in utility bills (Arrears); and (iii) living in a home with a leaking roof, or the presence of damp and rot (Housing faults):

$$
\text { Energy poverty index }=\left(\begin{array}{l}
0.5 \times \% \text { Inability }+0.25 \times \% \text { Arrears }+ \\
0.25 \times \% \text { Housing faults }
\end{array}\right) \times 100
$$

In the index, the indicator Inability received a higher weight in order to reflect the greater importance that our assessment gives to self-reported thermal discomfort levels in comparison with the indicator Arrears, which keeps track of late payment levels in energy and other utility bills. At the same time, Housing faults is closely related to, but not necessarily a direct indicator of, energy poverty. Our weighted values approach was thus based on previously developed energy poverty indices and weight values (Thomson \& Snell, 2013). It operated under the premise that consensual measures (such as the self-reported inability to keep warm) are insufficient to capture the complex economic and material underpinnings of energy poverty, and should be combined with indicators describing the housing and financial conditions of the population in order to obtain a fuller picture.

The resulting bivariate comparison (Table 4.1) showed a low degree of positive linear correlation between the energy poverty index and the at-riskof-poverty rate, even though relatively high levels of positive and statistically significant linear correlations were found to exist on an indicator-by-indicator

Table 4.1 Correlation matrix: Pearson's $r$ coefficients of linear correlation between SILC energy poverty indicators and index (columns) and the at-risk-ofpoverty rate (rows), calculated upon average values of EU-28 Member States for the period 2003-2013. Originally published in Bouzarovski and Tirado Herrero (2017a)

\begin{tabular}{lllll}
\hline & Inability & Arrears & $\begin{array}{l}\text { Housing } \\
\text { faults }\end{array}$ & $\begin{array}{l}\text { Energy } \\
\text { poverty index }\end{array}$ \\
\hline $\begin{array}{l}\text { At-risk-of-poverty rate (after } \\
\text { social transfers) }\end{array}$ & $0.523^{* *}$ & $0.574^{* *}$ & $0.480^{* *}$ & 0.264 \\
\hline
\end{tabular}

${ }^{* *} p<0.01 ;{ }^{*} p<0.05$ level 


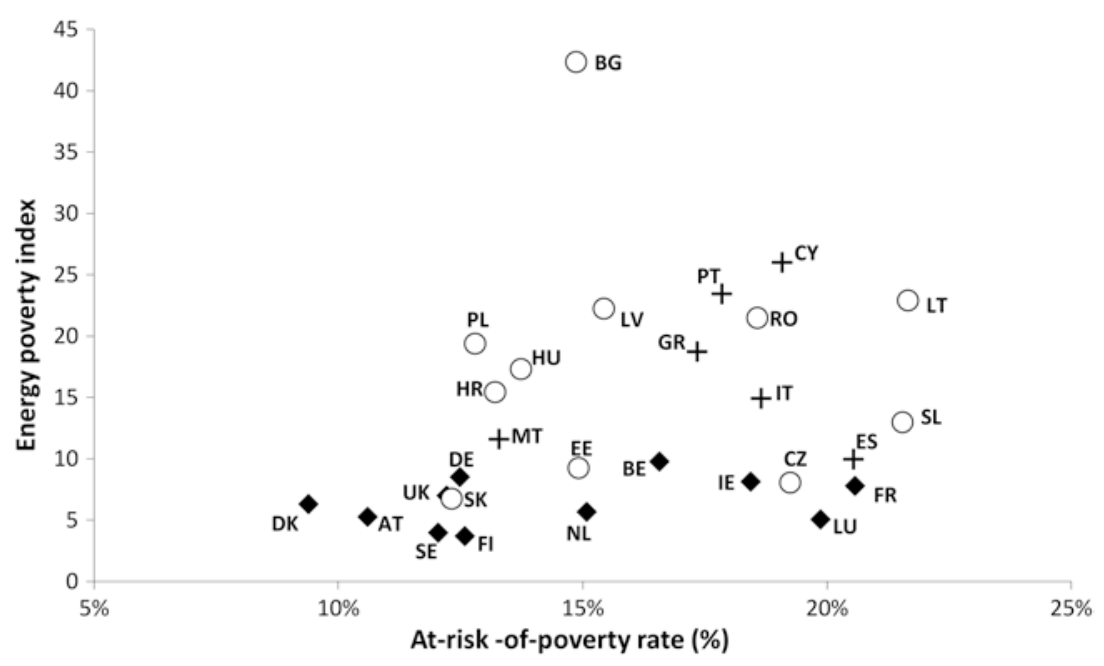

Fig. 4.2 Percentage of people at risk of poverty versus the energy poverty index. Average for EU member states 2003-2013 for both variables. Originally published in Bouzarovski and Tirado Herrero (2017b)

basis. In terms of macro-regions identified for the spatial analysis of energy poverty trends in the EU (Fig. 4.2), Western and Northern countries (noted in black diamonds) belong to a compact cluster reporting low energy poverty levels in relation to the at-risk-of-poverty rate. At the same time, Southern (crosses) and ECE Member States (circles) form a more heterogeneous group. They are characterized by energy poverty index values that are higher in relation to their at-risk-of-poverty-rates. With respect to the measurement of poverty and social exclusion, these results highlight the importance of material and housing deprivation dimensions, such as the inability to keep the home adequately warm. They emphasize the need for moving beyond purely monetary indicators, such as the at-risk-ofpoverty rate.

Thus, it can be argued that a core versus periphery distribution is a better descriptor of the spatial disparities in energy poverty rates across the EU than the traditional three-region model. The resulting European infrastructural divide is enmeshed in the improved macroeconomic performance and income levels among the latter group of states, as well as their higher-quality housing stock and more effective targeting of vulnerable 
groups. Overall, the principal differences between core and periphery countries are reflected in the degree of public recognition received by energy poverty, its socio-demographic extent as well as the structural drivers of the condition. While cultural differences may partly explain the disproportionately high prevalence of self-reported inadequately heated homes in Eastern, Central and Southern Europe, there is little doubt that energy poverty is objectively present in these parts of the continent to a much higher extent than elsewhere.

The structural causes of energy poverty in the two regions, however, are markedly different. As was pointed out in the previous sections of this chapter, ECE states have provided fertile ground for the expansion of energy poverty due to the unique combination of cold climates, aboveaverage rates of inefficient residential buildings, insufficiently developed and/or decaying infrastructure, high rates of income inequality and systemic issues in the management of energy, social welfare and housing operations. The socialist centrally planned economy left behind an energy sector that was entirely state-owned and -run, with indirect cross-subsidies from industry to the residential sector creating a pricing structure whereby household energy tariffs were set at below cost-recovery levels. Consequently, most countries in the region undertook dramatic price increases in order to remove such subsidies, while unbundling and privatizing energy companies so as to open up the industry to competition.

During the post-socialist transition, however, most governments were unable to provide adequate social assistance and energy efficiency investment to protect vulnerable households from energy price increases. This meant that many families had no option other than to cut back on their energy purchases. The concurrent rise in income inequality and overall poverty, alongside the initial lack of concerted efforts to improve the energy efficiency of rapidly decaying housing stocks and energy infrastructures, has created a situation whereby energy poverty now includes large parts of the population. In Poland, for example, the average 'energy burden' (the share of energy expenditure within total household expenditure) has been steadily increasing throughout the post-socialist period, even though both absolute and relative poverty have fallen during the same period. This suggests that energy affordability problems are widespread among the population, and that the expansion of economic prosperity is failing to relieve the pressure of rising energy costs on household budgets.

In Bouzarovski et al. (2016) we found that energy burdens have been on the rise particularly rapidly in Hungary: from 11.6 per cent in 2005 to 
16.9 per cent in 2011 . While the figures for Hungary point to the pervasive presence of energy poverty across the country, neighbouring Poland and Czechia also face difficult circumstances in this regard-in light of the fact that the literature on the subject considers energy burdens near or at 10 per cent as a sign of hardship (Boardman, 1991; Fankhauser \& Tepic, 2007), it is notable that significant numbers of households in all three countries have energy burdens above 20 per cent. This is where the comparatively greater size of the problem in Poland becomes more visible, as does the significant recent increase of the population affected by domestic energy deprivation in Hungary. In more general terms, it becomes apparent that post-communist energy sector reforms undertaken in all three countries-as well as the ability of nations like Poland to maintain GDP growth after the post-2008 financial crisis-have not translated into decreased energy costs or burdens for the general population and vulnerable groups alike.

The high prevalence of energy poverty in Southern European countries has been attributed to the lack of adequate heating systems, as well as the overall poor quality of residential dwellings, which has resulted in insufficient thermal insulation. In 2004, it was reported that only 12, 8, 6 and 16 per cent of Greek households had, respectively, cavity wall insulation, double-glazing, floor insulation and roof insulation in their homes (Healy, 2017). The situation was worse in Portugal, where the corresponding figures were 6, 3, 2 and 6 per cent. Nearly a quarter of Portuguese households had stated that they had rotten window frames, while a third revealed that they had patches of condensation on the indoor walls of their home (both of these conditions are considered good indicators of poor energy efficiency). Moreover, the same study found that 16, 19 and 11 per cent of households in, respectively, Greece, Portugal and Spain are suffering from leaking roofs, indicating the absence of adequate roof insulation. An additional problem in Mediterranean states is posed by the need for cooling. According to SILC data, 30 per cent of the population in the eight states bordering the Mediterranean Sea have reported that they are unable to keep their homes adequately cool in summer. Almost two-thirds of such households are considered income poor, while 70 per cent of them are above 65 years of age.

Countries such as the RoI, the UK-and to a lesser extent Belgium and France-constitute a third geographical realm with above-average rates of energy poverty in the EU. For example, it has been reported that indoor damp, itself a very strong indicator of energy poverty, is particularly prevalent 
in these countries (Healy \& Clinch, 2002). For the reasons outlined above, the RoI and the UK developed a wide range of measures to combat the problem: in the UK, the Warm Homes and Energy Conservation Act, effective November 2000, resulted in the implementation of an unprecedented set of policies for fuel poverty reduction, embodied in the 2001 UK Fuel Poverty Strategy. According to this document, fuel poverty reduction targets should have been achieved by eliminating fuel poverty among 'vulnerable' households (older persons, sick and disabled households and families with children) by 2010 , expanding to all households by 2016 .

The large-scale geographic variations discussed above mean that energy poverty is particularly concentrated in Southeastern Europe, where millions of households are likely to be suffering from a lack of adequate domestic energy services. Conventionally vulnerable groups such as 'pensioners, unemployed, low income households' have been particularly hard-hit, especially in the states that have not yet developed 'adequate social safety mechanisms' to protect energy-poor consumers. The limited extent of certain types of networked energy infrastructures (particularly gas) means that, in addition to inefficient residential stocks and affordability issues, energy deprivation is also predicated upon the spatial and technical limitations associated with switching towards more affordable fuel sources in the home. The demise of district heating systems-associated with spiralling supply costs and vicious cycles of disconnection, and coupled with rapidly rising electricity prices-has meant that some parts of the population have had no option other than using fuel wood for heating. This is particularly evident in Bulgaria, where switching towards this source of energy has a clear income dimension (Bouzarovski et al., 2012).

The substitution of modern energy carriers - mostly natural gas-by traditional or solid fuels for domestic energy heating has been reported in several ECE states (Fankhauser \& Tepic, 2007; UNDP, 2004). It is evidenced by the fact that approximately 36 per cent of Hungarian households were relying on solid fuels in 2011 , as opposed to 14 per cent in 2005 . The trend transpired despite the presence of piped gas links in 76 per cent of dwellings and 96 per cent of settlements in Hungary, even if the amount of natural gas consumed per household dropped from $1457 \mathrm{~m}^{3}$ per year in 2005 to $934 \mathrm{~m}^{3}$ per year in 2011 . The reliance on solid fuels has displayed a powerful income differential, with over half of all households in the bottom income decile resorting to this source of energy (Table 4.2). The propensity for lower-income households to consume solid fuels is indicative of the increasing inequality in the purchasing power of households, rather than matters of evolving cultural or economic preferences. 
Table 4.2 Percentage of Hungarian households who dedicated more than 10 per cent of their energy expenditure to solid fuels in 2005 and 2011, by income deciles. Originally published in Bouzarovski et al. (2016)

\begin{tabular}{lcccccccccc}
\hline Income deciles & 1 & 2 & 3 & 4 & 5 & 6 & 7 & 8 & 9 & 10 \\
\hline 2005 & 57 & 39 & 33 & 31 & 25 & 25 & 24 & 17 & 12 & 5 \\
2011 & 60 & 48 & 48 & 44 & 43 & 39 & 33 & 31 & 21 & 13 \\
\hline
\end{tabular}

As a result of these developments, firewood-the dominant solid fuel consumed by Hungarian households, alongside coal and woodchips-now trails natural gas as the second most common energy carrier for domestic space heating, even though both fuels are often used synchronously.

\section{Difference Within Countries, Regions AND Social Groups}

Overall, the academic literature has found above-average rates of energy poverty among older people, families with children, and households with disabilities, long-term illness, or infirmity (Bouzarovski, 2014). In the Irish context, for instance, 'over half of elderly households endure inadequate ambient household temperatures during winter' (Healy \& Clinch, 2002, p. 329). The EPEE project has also identified as vulnerable populations those out of work or in poorly paid jobs, and those dependent on social security benefits. Earlier, it was established that the group most susceptible to persistent energy poverty in the 'older' EU-15 states is single parents, followed by lone pensioners (Gray, 1995). It has also transpired that households living in multi-family apartment blocks are more likely to be suffering from energy poverty if they live in Northern as opposed to Southern Europe, partly due to income differentials. Tenure has also shown to be an important predictor of energy poverty, with households living in rental homes more vulnerable to the condition (Bouzarovski, 2014).

The scale of the energy burden is often a good predictor of the sociodemographic groups suffering from energy poverty. In Poland, for example, disproportionate expenditure on energy is correlated to household size among pensioners, with lone pensioners facing particular difficulties (ibid.). Above-average rates of energy expenditure can also be found in the case of all households headed by 'manual' workers and farmers. On average, large households are more likely to suffer from this condition compared to medium-sized households. Similar trends can be found across other Eastern European states. 
Micro-scale social and residential typologies of energy poverty aggregate across broader spaces and scales to produce specific geographical patterns of vulnerability. Thus, Household Budget Survey (HBS) data for Hungary show that households with high energy burdens and facing a situation of low energy and high incomes (alike the LIHC [Low Income High Cost] indicator described in Chap. 2) are disproportionately concentrated in suburban areas, villages and areas with 'poor housing' as defined by the national statistical office (Table 4.3). This confirms previous indications about the prevalence of domestic energy deprivation in rural areas. With the exception of the 'poor housing' category, self-reported inadequate domestic

Table 4.3 Energy poverty indicators for selected housing typologies in Hungary (expressed as shares of households in the relevant category within all households). Above-average values are italicized and shaded. Originally published in Bouzarovski and Tirado Herrero (2017a)

\begin{tabular}{|l|c|c|c|c|}
\hline \multicolumn{1}{|c|}{ Indicators } & $\begin{array}{c}\text { Energy } \\
\text { burden } \\
\text { exceeds 20 } \\
\text { per cent }\end{array}$ & LIHC & $\begin{array}{c}\text { Dwelling un- } \\
\text { comfortably } \\
\text { warm in } \\
\text { winter }\end{array}$ & $\begin{array}{c}\text { Dwelling un- } \\
\text { comfortably } \\
\text { cool in } \\
\text { summer }\end{array}$ \\
\hline Total household share & $\mathbf{3 1}$ & $\mathbf{1 3}$ & $\mathbf{2 0}$ & $\mathbf{2 7}$ \\
\hline Urban area & 21 & 7 & 24 & 31 \\
\hline Housing estate, & 19 & 7 & 15 & 52 \\
\hline apartment block & 15 & 7 & 14 & 18 \\
\hline 'Garden suburb** & 36 & 14 & 21 & 17 \\
\hline Suburban area** & 41 & 19 & 20 & 16 \\
\hline Village & 19 & 7 & 37 & 40 \\
\hline Industrial area & 36 & 16 & 73 & 53 \\
\hline Area with poor housing & 66 & 13 & 22 & 22 \\
\hline Other & & & \\
\hline
\end{tabular}

${ }^{*}$ Cottages, dwellings in multi-apartment buildings

** Detached houses 
heating and cooling rates diverge from such metrics, as evidenced by the above-average concentration of households experiencing such conditions in urban and industrial areas, as well as suburbs in the case of heating and apartment blocks in the case of cooling. Overall, this points to the influence of housing stock characteristics in influencing the quality of the final energy services received by households.

The spatial distributions of above 20 per cent energy burden and LIHC household shares in Poland and Czechia exhibit similar spatial patterns, with areas of low and medium population density hosting above-average numbers of families experiencing such difficulties (Table 4.4). Inadequately

Table 4.4 Energy poverty indicators for selected housing typologies in Hungary (expressed as shares of households in the relevant category within all households). Above-average values of the 'category' shares are italicized and shaded. Originally published in Bouzarovski and Tirado Herrero (2017a)

\begin{tabular}{|c|c|c|c|c|c|c|c|c|}
\hline Indicator & \multicolumn{2}{|c|}{$\begin{array}{c}\text { Energy } \\
\text { burden } \\
\text { exceeds } 20 \text { per } \\
\text { cent }\end{array}$} & \multicolumn{2}{|c|}{ LIHC } & \multicolumn{2}{|c|}{$\begin{array}{c}\text { Dwelling } \\
\text { insufficiently } \\
\text { warm in } \\
\text { winter }\end{array}$} & \multicolumn{2}{|c|}{$\begin{array}{c}\text { Dwelling } \\
\text { insufficiently } \\
\text { cool in } \\
\text { summer }\end{array}$} \\
\hline Household share & $\begin{array}{l}\text { Cate- } \\
\text { gory }\end{array}$ & Total & $\begin{array}{l}\text { Cate- } \\
\text { gory }\end{array}$ & Total & $\begin{array}{l}\text { Cate- } \\
\text { gory }\end{array}$ & Total & $\begin{array}{l}\text { Cate- } \\
\text { gory }\end{array}$ & Total \\
\hline \multicolumn{9}{|c|}{ Area with a high population density } \\
\hline Poland & 15 & 20 & 10 & 14 & 14 & 13 & 24 & 19 \\
\hline Czechia & 8 & 12 & 6 & 9 & - & - & - & - \\
\hline \multicolumn{9}{|c|}{ Medium population density } \\
\hline Poland & 21 & 20 & 15 & 14 & 11 & 13 & 17 & 19 \\
\hline Czechia & 13 & 12 & 10 & 9 & - & - & - & - \\
\hline \multicolumn{9}{|c|}{ Low population density } \\
\hline Poland & 25 & 20 & 18 & 14 & 14 & 13 & 16 & 19 \\
\hline Czechia & 15 & 12 & 11 & 9 & - & - & - & - \\
\hline
\end{tabular}


cool and warm homes in these two countries, however, are generally more present in high-density regions, possibly pointing to the urban character of such circumstances.

Energy deprivation indicators also exhibit different forms of geographical variation within the three study countries. Capital city regions in Czechia, Hungary and Poland alike are notable for the low concentrations of households with high LIHC scores or energy burdens (Fig. 4.3). The share of

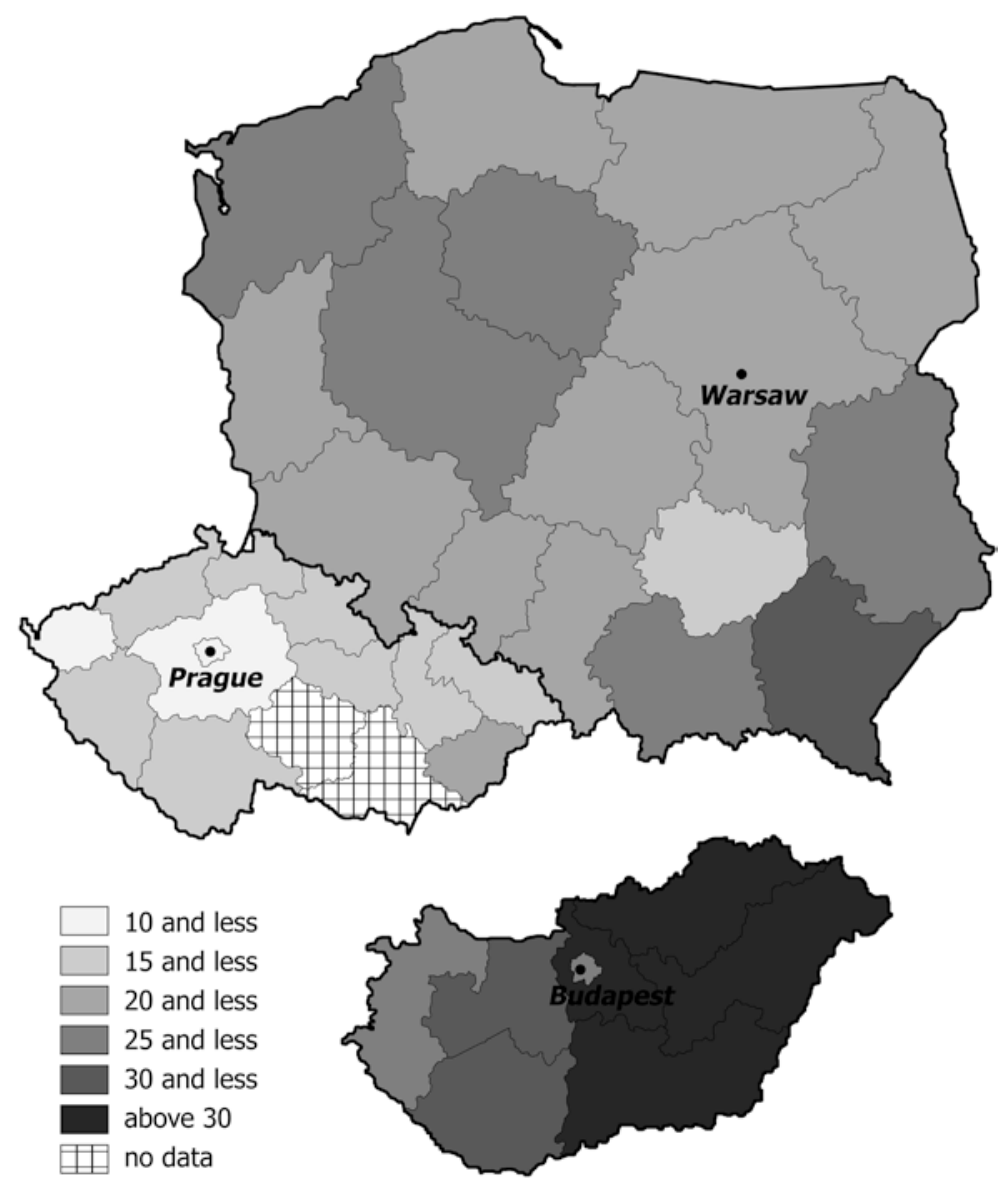

Fig. 4.3 Regional variation in the shares of households that experienced energy burdens above 20 per cent in three Central European countries. Originally published in Bouzarovski and Tirado Herrero (2017a) 
households experiencing energy burdens above 20 per cent follows is a clear east-west gradient in Hungary-with the predominantly agricultural and economically underdeveloped eastern parts of the country registering record percentage levels of this indicator. A more concentric pattern (focusing on Prague) seems to be present in Czechia, with the thinly populated resource periphery of the Zlín region ranking the highest according to this statistic. The northeastern and southeastern parts of Poland are more vulnerable than the rest of the country, especially the rural Podkarpackie region at the border with Ukraine and Slovakia. The relatively privileged position of capital cities can also be seen in the regional patterns of LIHC household shares (Fig. 4.4), even if a more differentiated picture emerges at the national scale: the highest values can be found in southeastern Hungary (the northeast seems to be faring relatively better) as well as a number of regions in central, northeastern and northwestern Poland. This is despite the fact that the far southeast still has the highest percentages of households with LIHC. The Zlín region is still the most vulnerable in Czechia in LIHC terms, albeit this statistic also identifies two neighbouring Northern Moravia regions as well as the far northwest Karlovy Vary region as susceptible to the condition.

It is important to note the lack of a direct correspondence between above-average household percentages of the energy burdens and LIHC indicators, on the one hand, and per capita GDP values, on the other. Thus, the lowest levels of per capita economic output can be found in the Hungarian northeast, even if LIHC percentages are highest in the southeast (Fig. 4.5). The deprived northwest and northeast regions of Czechia do not appear to concentrate above-average numbers of energy-poor households. The discrepancy between more conventional patterns of economic inequality and domestic energy deprivation indicators is also apparent in Poland, where, for example, the relatively underdeveloped Opolskie and Lubuskie Voivodeships close to, respectively, the Czech and German borders rank relatively low on the energy burden and LIHC scores; the same applies to the entire northeast of the country, where GDP per capita levels are even lower. The picture becomes even more complex if self-reported levels of inadequate domestic heating or cooling are explored at the regional scale (Fig. 4.5). Polish regions hosting larger urban centres (e.g. Warsaw, Wroclaw Lodz and Szcecin) appear to be more vulnerable according to these measures. In Hungary, some of the highest values have been reported for the capital Budapest and its surroundings. Notably, three Eastern Hungarian regions are characterized by higher or equal percentages of households who feel their home is poorly 


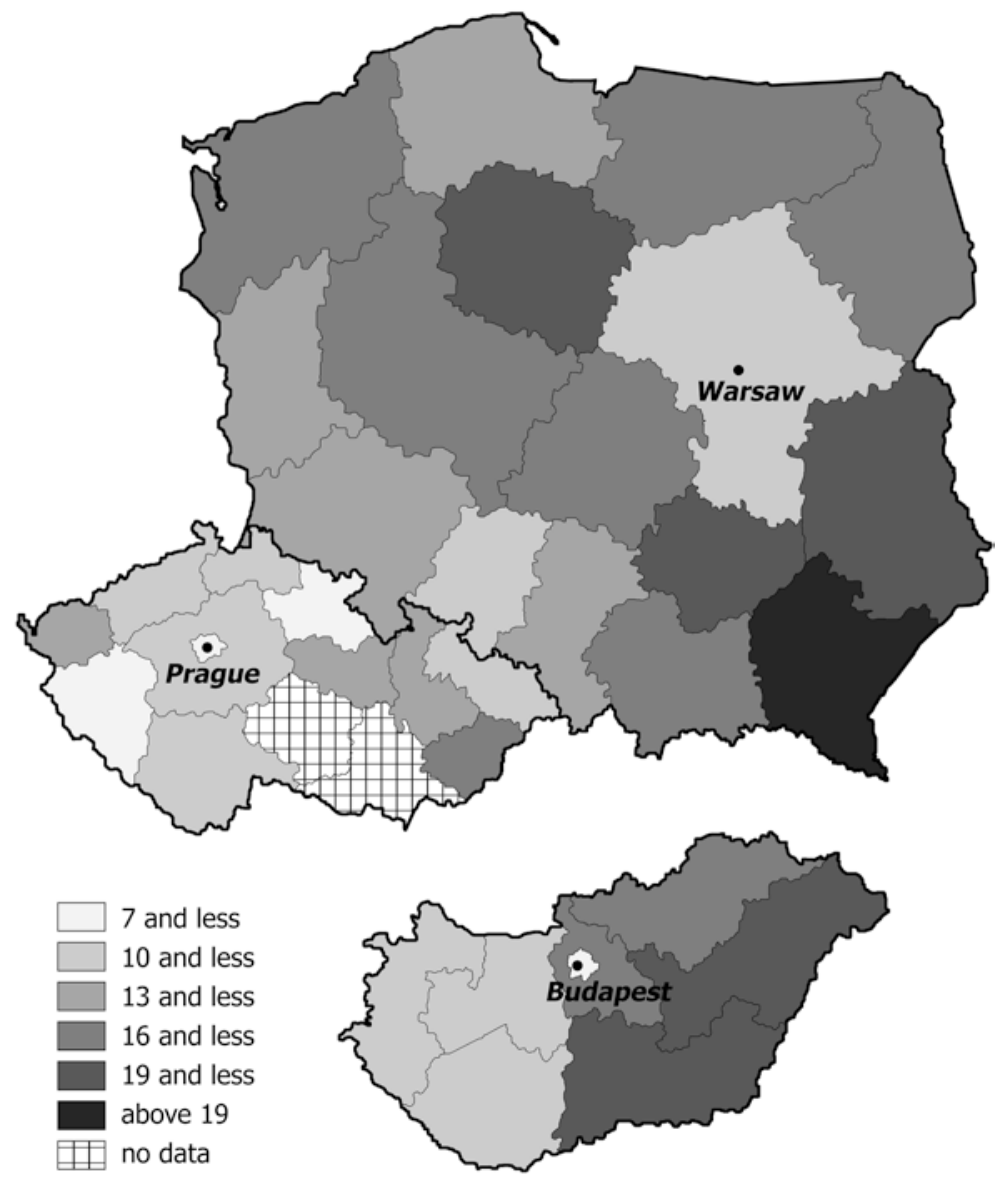

Fig. 4.4 Regional variation in the shares of households that were energy poor according to the LIHC indicator, in three Central European countries. Originally published in Bouzarovski and Tirado Herrero (2017a)

heated, when compared to being poorly cooled-a trend that diverges from the remainder of their host country, and all of Poland. When considered together with the values of expenditure-based indicators for the three regions in question, this trend may point to the severity of energy poverty in the eastern part of Hungary as a whole. 


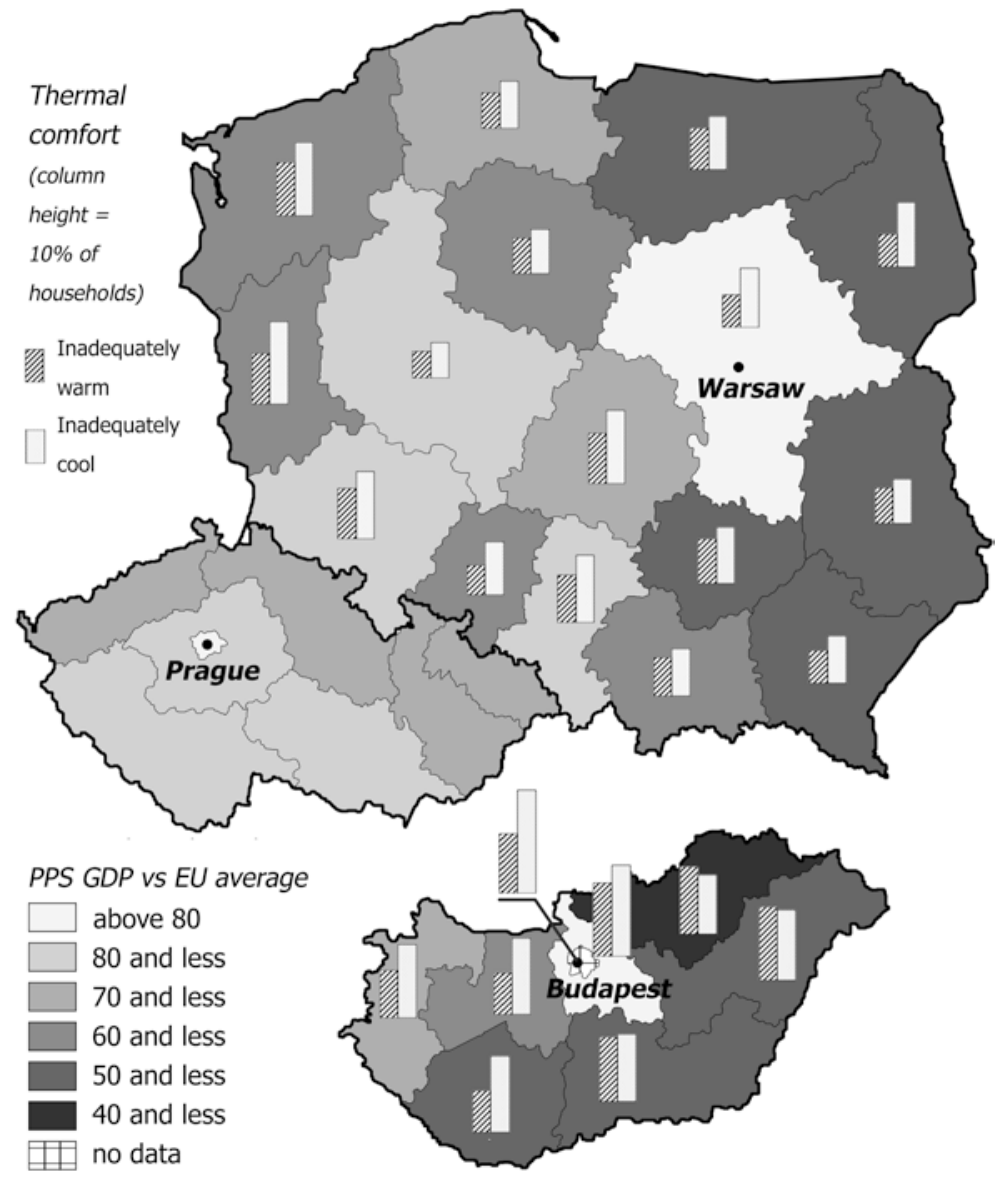

Fig. 4.5 Regional variation in the shares of Hungarian and Polish households that experienced inadequately warm or cool homes, mapped against PPP (purchasing power parity)-adjusted GDP per capita figures. Originally published in Bouzarovski and Tirado Herrero (2017a)

Czech data on the relationship between settlement size, on the one hand, and LIHC or high energy burden household shares, on the other, may help explain the broader geographical distribution of energy poverty indicators in this country (Fig. 4.6). The highest proportions of households 


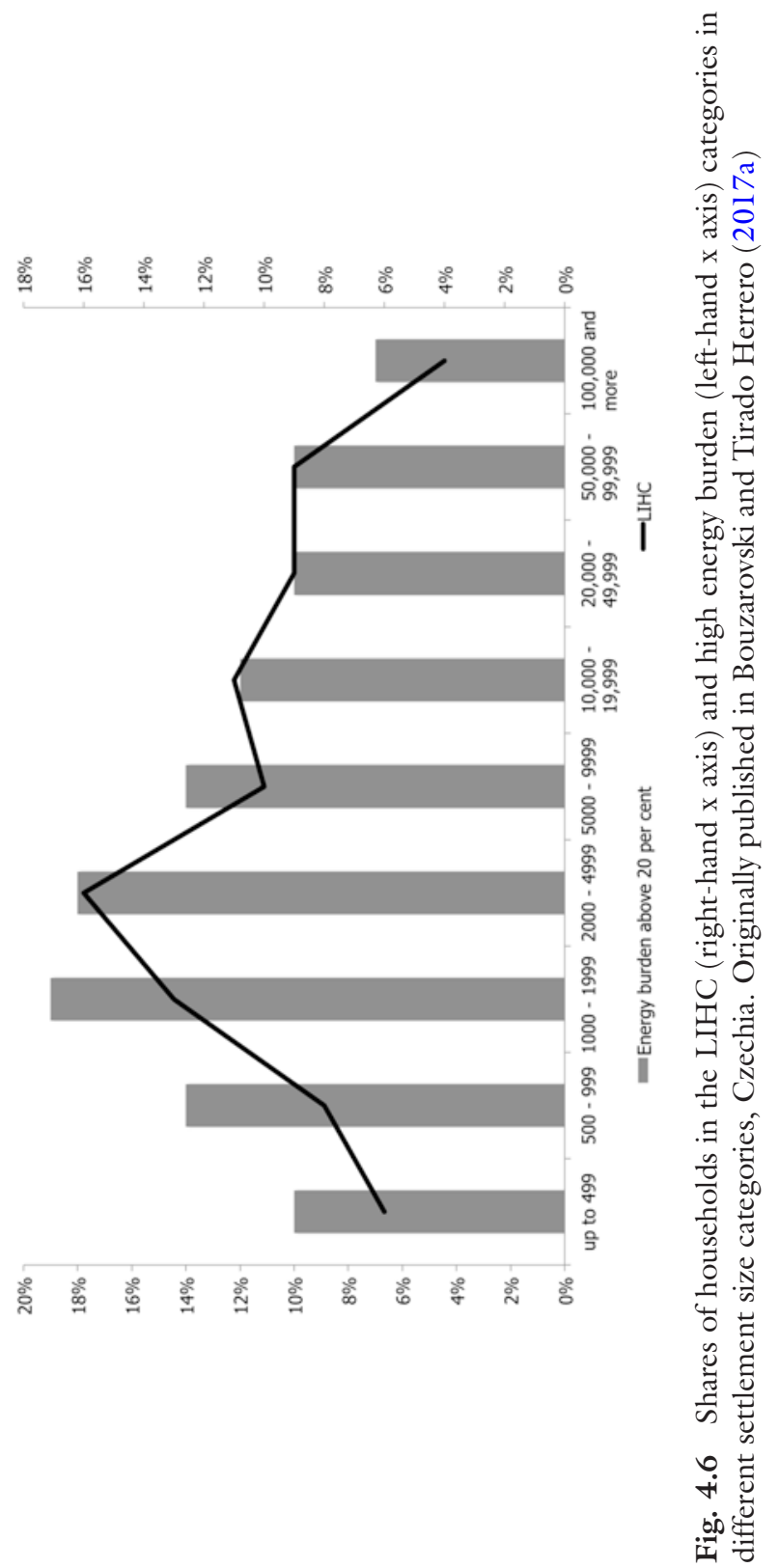


with high energy burdens and costs can be found in small- to medium-sized towns. Such areas have been marginalized in housing refurbishment programmes, while facing a range of issues surrounding the legal and technical restructuring of the housing stock. The prevalence of medium- and smallsized settlements in regions like Zlín or Karlovy Vary-as opposed to the economically more deprived but also more urbanized northwestern and northeastern parts of the country - may explain the configurations of regional inequality described above. At the same time, fuel prices and availability may have played a role in the geographical distribution of energy poverty indicators in Poland and Hungary; regions where biomass and coal are more abundant perform better on the LIHC and energy burden despite the low incomes of the population. This may be due to wider price effects, as our analyses in Bouzarovski and Tirado Herrero (2017a) have also shown an increased incidence of the LIHC and high energy burden indicators in households who use solid fuels as the main source of warmth (Table 4.5). As a whole, the reviewed evidence suggests that the demand-side fuel mix and the condition of the housing stock have combined with existing patterns of deprivation to produce new spatial distributions of energy poverty at the subnational level.

\section{CONCLUSION}

There is little doubt that energy poverty is a pervasive problem across the $\mathrm{EU}$, and is likely to expand in coming years as a result of anticipated energy price increases. For a long time, however, systematic research on issues of domestic energy deprivation in the much of the EU was scarce, especially in the countries of ECE and the Mediterranean where this condition is likely to be most pronounced. This means that, other than the UK and the RoI-which have a longer tradition of academic scholarship and policy frameworks to address the issue-energy poverty measures in many EU Member States are of an emergent nature.

Understanding the causes, content and consequences of European energy poverty is all the more pertinent in light of the increasing policy attention that is being paid to the issue within various EU institutions. In contrast to many mainstream efforts to reduce the problem to affordability or income poverty issues, however, much of the scholarship on the problem shows that the physical and institutional arrangements underlying built environment formations and everyday household practices are just as important in this context. Thus, enabling households to access energy at a materially and socially necessitated level is just as much a question of ensuring an 
Table 4.5 Housing-related indicators of vulnerability to energy poverty. In the table, 'category' refers to the share of households that are considered vulnerable to the given indicator within the specific socio-demographic category; 'total' refers to the cumulative share of households in the sample (i.e. as a proportion of all households) that are considered vulnerable to the given indicator. Above-average values of the 'category' shares are italicized and shaded. Originally published in Bouzarovski and Tirado Herrero (2017a)

\begin{tabular}{|c|c|c|c|c|c|c|c|c|}
\hline \multirow{2}{*}{$\begin{array}{l}\text { Indicators } \\
\\
\text { Household }\end{array}$} & \multicolumn{2}{|c|}{$\begin{array}{l}\text { Energy burden } \\
\text { exceeds } 20 \text { per } \\
\text { cent }\end{array}$} & \multicolumn{2}{|c|}{ LIHC } & \multicolumn{2}{|c|}{$\begin{array}{c}\text { Dwelling } \\
\text { insufficiently* } \\
\text { warm in } \\
\text { winter }\end{array}$} & \multicolumn{2}{|c|}{$\begin{array}{c}\text { Dwelling } \\
\text { insufficiently* } \\
\text { cool in } \\
\text { summer }\end{array}$} \\
\hline & $\begin{array}{l}\text { Cate- } \\
\text { gory }\end{array}$ & Total & $\begin{array}{l}\text { Cate- } \\
\text { gory }\end{array}$ & Total & $\begin{array}{l}\text { Cate- } \\
\text { gory }\end{array}$ & Total & $\begin{array}{l}\text { Cate- } \\
\text { gory }\end{array}$ & Total \\
\hline \multicolumn{9}{|c|}{ Solid or liquid fuels provide the main source of indoor warmth } \\
\hline Hungary & 38 & 31 & 16 & 13 & 27 & 20 & 19 & 27 \\
\hline Poland & 25 & 20 & 19 & 14 & 35 & 13 & 26 & 19 \\
\hline Czechia & 19 & 12 & 11 & 9 & - & - & - & - \\
\hline \multicolumn{9}{|c|}{ Electricity provides the main source of indoor warmth } \\
\hline Hungary & 39 & 31 & 16 & 13 & 34 & 20 & 30 & 27 \\
\hline Poland* & 22 & 20 & 11 & 14 & 26 & 13 & 20 & 19 \\
\hline Czechia & 15 & 12 & 14 & 9 & - & - & - & - \\
\hline \multicolumn{9}{|c|}{ District heating provides the main source of indoor warmth } \\
\hline Hungary & 20 & 31 & 8 & 13 & 11 & 20 & 55 & 27 \\
\hline
\end{tabular}

(continued) 
Table 4.5 (continued)

\begin{tabular}{|c|c|c|c|c|c|c|c|c|}
\hline Poland & 14 & 20 & 10 & 14 & 8 & 13 & 23 & 19 \\
\hline Czechia & 7 & 12 & 6 & 9 & - & - & - & - \\
\hline \multicolumn{9}{|c|}{ Households living in dwellings constructed before $1945^{* *}$} \\
\hline Hungary & 31 & 31 & 13 & 13 & 28 & 20 & 20 & 27 \\
\hline Poland & 23 & 20 & 16 & 14 & 27 & 13 & 22 & 19 \\
\hline Czechia & 17 & 12 & 10 & 9 & - & - & - & - \\
\hline \multicolumn{9}{|c|}{ Households living in dwellings constructed between 1945 and 1960} \\
\hline Hungary & 36 & 31 & 16 & 13 & 23 & 20 & 18 & 27 \\
\hline Poland & 23 & 20 & 17 & 14 & 15 & 13 & 19 & 19 \\
\hline Czechia & 14 & 12 & 13 & 9 & - & - & - & - \\
\hline \multicolumn{9}{|c|}{ Households living in rented accommodation $* * *$} \\
\hline Hungary & 20 & 31 & 6 & 13 & 32 & 20 & 44 & 27 \\
\hline Poland & 10 & 29 & 7 & 14 & 20 & 13 & 25 & 19 \\
\hline Czechia & 7 & 12 & 6 & 9 & - & - & - & - \\
\hline \multicolumn{9}{|c|}{ Households living in free or reduced rent accommodation $* * * * *$} \\
\hline Hungary & 29 & 31 & 9 & 13 & 23 & 20 & 35 & 27 \\
\hline Poland & 24 & 29 & 18 & 14 & 29 & 13 & 29 & 19 \\
\hline Czechia & 14 & 12 & 10 & 9 & - & - & - & - \\
\hline
\end{tabular}

*Also includes gas

** Does not include dwellings older than 1900 for Hungary

***In Czechia and Poland this is the non-weighted average of households living in rent-controlled and free market rental accommodation as reported by the HBS

****Free accommodation in Hungary and Czechia, reduced rent accommodation in Poland 
adequate match between housing types, heating systems and household needs as it is about incomes and energy efficiency. In broader terms, therefore, building a comprehensive EU energy poverty agenda requires a conceptual shift in the mainstream theorization of domestic energy deprivation, away from the relatively narrow focus on poverty, access and energy efficiency, onto more complex and nuanced issues of household needs, built environment flexibility and social resilience.

The reviewed evidence also indicates that the driving forces of energy poverty are themselves embedded in locally specific social, political and environmental circumstances. For example, even though countries with colder climates would be expected to exhibit a greater incidence of energy poverty, the size of the population affected by domestic energy deprivation is estimated to be the lowest in Scandinavia; conversely, it has reached record levels in Southern Europe, where higher rates of income poverty and poorly insulated homes are clearly playing a determining role, in addition to the fact that many dwellings lack satisfactory heating systems. Similarly, despite possessing some of the highest energy prices in Europe, the incidence of energy poverty in Germany is judged to be significantly lower than that in, for example, Bulgaria, where energy prices are comparatively modest. In case of the latter, however, the underlying causes of the problem reside in the poor affordability of gas, electricity and heat services and the inadequate energy efficiency of the residential sector.

Much of the reviewed literature shows that energy poverty in many vulnerable 'peripheral' EU countries is expanding, while encompassing populations well beyond the low-income bracket. This is unlike better-off states - primarily in the North and West-where domestic energy deprivation seems to be predominantly concentrated among specific sociodemographic groups. Thus, the ability to capture energy poverty via the lens of income-based indicators is less meaningful in contexts where difficulties in securing adequate levels of energy services in the home are common within the general population. There is also evidence pointing to the presence of a distinct geographic distribution of energy poverty across Europe, whereby the socio-spatial underpinnings of the condition are aggregated with wider patterns of economic inequality. In many Eastern, Central and Southern EU Member States in particular, there is a tendency for domestic energy deprivation to be concentrated in rural and peripheral regions with poor-quality housing and decreased access to affordable fuels. 


\section{REFERENCES}

Atsalis, A., Mirasgedis, S., Tourkolias, C., \& Diakoulaki, D. (2016). Fuel poverty in Greece: Quantitative analysis and implications for policy. Energy and Buildings, 131, 87-98.

Bacon, R. (1994). Measurement of welfare change caused by large price shifts. Washington, DC: World Bank.

Bafoil, F., Fodor, F., \& le Roux, D. (2014). What energy for the Europe of the poor? A European comparison of Great Britain, France, Germany, Poland, Hungary. Paris: Presses de Sciences Po.

Bartiaux, F., Gosselain, V., Vassileva, D., Stamova, G., Ozolina, L., \& Gara, E. (2012). Knowledge on climate change and energy saving renovations by apartment owners in Bulgaria and Latvia. A qualitative study (Unpublished manuscript).

Bartl, M. (2010). The affordability of energy: How much protection for the vulnerable consumers? Journal of Consumer Policy, 33, 225-245.

Becker, S., Kouschil, K., \& Naumann, M. (2014). Armut und Infrastruktur: das Beispiel Energiearmut. Geographische Rundschan, 66, 10-17.

Billen, G. (2008). Energie-Sozialtarife: Antwort auf drohende Energiearmut? Wirtschaftsdienst, 88, 489-490.

Boardman, B. (1991). Fuel poverty: From cold homes to affordable warmth. London: Belhaven.

Boardman, B. (2010). Fixing fuel poverty: Challenges and solutions. London: Routledge.

Boemi, S.-N., Avdimiotis, S., \& Papadopoulos, A. M. (2017). Domestic energy deprivation in Greece: A field study. Energy and Buildings, 144, 167-174.

Boemi, S.-N., \& Papadopoulos, A. M. (2017). Monitoring energy poverty in Northern Greece: The energy poverty phenomenon. International Journal of Sustainable Energy, 0, 1-15.

Bouzarovski, S. (2014). Energy poverty in the European Union: Landscapes of vulnerability. Wiley Interdisciplinary Reviews: Energy and Environment, 3, 276-289.

Bouzarovski, S. (2015). Retrofitting the city: Residential flexibility, resilience and the built environment. London: IB Tauris.

Bouzarovski, S., Petrova, S., \& Sarlamanov, R. (2012). Energy poverty policies in the EU: A critical perspective. Energy Policy, 49, 76-82.

Bouzarovski, S., \& Simcock, N. (2017). Spatializing energy justice. Energy Policy, 107, 640-648.

Bouzarovski, S., \& Tirado Herrero, S. (2017a). Geographies of injustice: The socio-spatial determinants of energy poverty in Poland, Czechia and Hungary. Post-Communist Economies, 29, 27-50. 
Bouzarovski, S., \& Tirado Herrero, S. (2017b). The energy divide: Integrating energy transitions, regional inequalities and poverty trends in the European Union. European Urban and Regional Studies, 24, 69-86.

Bouzarovski, S., Tirado Herrero, S., Petrova, S., \& Ürge-Vorsatz, D. (2016). Unpacking the spaces and politics of energy poverty: Path-dependencies, deprivation and fuel switching in post-communist Hungary. Local Environment, 21, $1151-1170$.

Brunner, K.-M., Spitzer, M., \& Christanell, A. (2012). Experiencing fuel poverty. Coping strategies of low-income households in Vienna/Austria. Energy Policy, 49, 53-59.

Buckley, R. M., \& Gurenko, E. N. (1997). Housing and income distribution in Russia: Zhivago's legacy. The World Bank Observer, 12, 19-32.

Buzar, S. (2007a). Energy poverty in Eastern Europe: Hidden geographies of deprivation. Aldershot: Ashgate.

Buzar, S. (2007b). The 'hidden' geographies of energy poverty in post-socialism: Between institutions and households. Geoforum, 38, 224-240.

Buzar, S. (2007c). When homes become prisons: The relational spaces of postsocialist energy poverty. Environment and Planning A, 39, 1908-1925.

Cirman, A., Mandič, S., \& Zorić, J. (2013). Decisions to renovate: Identifying key determinants in Central and Eastern European post-socialist countries. Urban Studies, 50, 3378-3393.

Dodonov, B., Opitz, P., \& Pfaffenberger, W. (2004). How much do electricity tariff increases in Ukraine hurt the poor? Energy Policy, 32, 855-863.

Dubois, U. (2012). From targeting to implementation: The role of identification of fuel poor households. Energy Policy, 49, 107-115.

European Bank for Reconstruction and Development. (2003). Can the poor pay for power? The affordability of electricity in South East Europe. London: EBRD and IPA Energy.

European Commission. (2013). Vulnerable consumer working group guidance document on vulnerable consumers, November 2013. Brussels: European Commission, Vulnerable Consumer Working Group.

Fankhauser, S., \& Tepic, S. (2007). Can poor consumers pay for energy and water? An affordability analysis for transition countries. Energy Policy, 35, 1038-1049.

Florio, M. (2013). Network industries and social welfare: The experiment that reshuffled European utilities. Oxford: Oxford University Press.

Freund, C. L., \& Wallich, C. I. (1996). The welfare effects of raising household energy prices in Poland. The Energy Journal, 17, 53-77.

Gray, D. (1995). Reforming the energy sector in transition economies: Selected experience and lessons. Washington, DC: World Bank.

Großmann, K., Schaffrin, A., \& Smigiel, C. (Eds.). (2016). Energie und soziale Ungleichbeit: Zur gesellschaftlichen Dimension der Energiewende in Deutschland und Europa. Wiesbaden: Springer. 
Healy, J. (2003). Excess winter mortality in Europe: A cross country analysis identifying key risk factors. Journal of Epidemiology and Community Health, 57, 784-789.

Healy, J. D. (2017). Housing, fuel poverty and health: A pan-European analysis. Abingdon/New York: Routledge.

Healy, J. D., \& Clinch, J. P. (2002). Fuel poverty, thermal comfort and occupancy: Results of a national household-survey in Ireland. Applied Energy, 73, 329-343.

Katsoulakos, N. (2011). Combating energy poverty in mountainous areas through energy-saving interventions. Mountain Research and Development, 31, 284-292.

Katsoulakos, N. M., \& Kaliampakos, D. C. (2016). Mountainous areas and decentralized energy planning: Insights from Greece. Energy Policy, 91, 174-188.

Kolokotsa, D., \& Santamouris, M. (2015). Review of the indoor environmental quality and energy consumption studies for low income households in Europe. Science of the Total Environment, 536, 316-330.

Kopatz, M. (2009). Energiearmut in Deutschland: Brauchen wir einen Sozialtarif? Energiewirtschaftliche Tagesfragen, 59, 48-51.

Kovačević, A. (2004). Stuck in the past: Energy, environment and poverty in Serbia and Montenegro. Belgrade: United Nations Development Programme.

Lampietti, J., \& Meyer, A. (2002). When heat is a luxury: Helping the urban poor of Europe and Central Asia cope with the cold. Washington, DC: World Bank.

Legendre, B., \& Ricci, O. (2015). Measuring fuel poverty in France: Which households are the most fuel vulnerable? Energy Economics, 49, 620-628.

Lenz, N. V., \& Grgurev, I. (2017). Assessment of energy poverty in new European Union member states: The case of Bulgaria, Croatia and Romania. International Journal of Energy Economics and Policy, 7, 1-8.

Liddell, C., \& Morris, C. (2010). Fuel poverty and human health: A review of recent evidence. Energy Policy, 38, 2987-2997.

März, S. (2017). Assessing the fuel poverty vulnerability of urban neighbourhoods using a spatial multi-criteria decision analysis for the German city of Oberhausen. Renewable and Sustainable Energy Reviews. https://doi.org/10.1016/j. rser.2017.07.006.

Maxim, A., Mihai, C., Apostoaie, C.-M., \& Maxim, A. (2017). Energy poverty in Southern and Eastern Europe: Peculiar regional issues. European Journal of Sustainable Development, 6, 247.

Miazga, A., \& Owczarek, D. (2015). It's cold inside - Energy poverty in Poland. Warsaw: Institute for Structural Research.

Miniaci, R., Scarpa, C., \& Valbonesi, P. (2008). Distributional effects of price reforms in the Italian utility markets. Fiscal Studies, 29, 135-163.

Ortar, N. (2016). Dealing with energy crises: Working and living arrangements in peri-urban France. Transport Policy. https://doi.org/10.1016/j.tranpol.2016. 09.008 . 
Papada, L., \& Kaliampakos, D. (2017). Energy poverty in Greek mountainous areas: A comparative study. Journal of Mountain Science, 14, 1229-1240.

Petrova, S. (2017). Illuminating austerity: Lighting poverty as an agent and signifier of the Greek crisis. European Urban and Regional Studies. https://doi. org/10.1177/0969776417720250.

Phimister, E., Vera-Toscano, E., \& Roberts, D. (2015). The dynamics of energy poverty: Evidence from Spain. Economics of Energy and Environmental Policy, $4,153-166$.

Pye, S., Baffert, C., Brajković, J., Grgurev, I., Miglio, D. R., \& Deane, P. (2015). Energy poverty and vulnerable consumers in the energy sector across the EU: Analysis of policies and measures. London: Insight_E.

Rezessy, S., Dimitrov, K., Ürge-Vorsatz, D., \& Baruch, S. (2006). Municipalities and energy efficiency in countries in transition. Review of factors that determine municipal involvement in the markets for energy services and energy efficient equipment, or how to augment the role of municipalities as market players. Energy Policy, 34, 223-237.

Sánchez-Guevara Sánchez, C., Mavrogianni, A., \& Neila González, F. J. (2017). On the minimal thermal habitability conditions in low income dwellings in Spain for a new definition of fuel poverty. Building and Environment, 114, 344-356.

Santamouris, M., Alevizos, S. M., Aslanoglou, L., Mantzios, D., Milonas, P., Sarelli, I., ... Paravantis, J. A. (2014). Freezing the poor-Indoor environmental quality in low and very low income households during the winter period in Athens. Energy and Buildings, 70, 61-70.

Santamouris, M., Kapsis, K., Korres, D., Livada, I., Pavlou, C., \& Assimakopoulos, M. N. (2007). On the relation between the energy and social characteristics of the residential sector. Energy and Buildings, 39, 893-905.

Scarpellini, S., Sanz Hernández, M. A., Llera-Sastresa, E., Aranda, J. A., \& López Rodríguez, M. E. (2017). The mediating role of social workers in the implementation of regional policies targeting energy poverty. Energy Policy, 106, 367-375.

Szivós, P., Bernát, A., \& Kőszeghy, L. (2011). Managing household debt: Hungarian country report. Budapest, Hungary: Tárki Social Research Institute.

Tews, K. (2014). Fuel poverty in Germany: From a buzzword to a definition. GAIA - Ecological Perspectives for Science and Society, 23, 14-18.

Thomson, H., \& Snell, C. (2013). Quantifying the prevalence of fuel poverty across the European Union. Energy Policy, 52, 563-572.

Thomson, H., Snell, C., \& Bouzarovski, S. (2017). Health, well-being and energy poverty in Europe: A comparative study of 32 European countries. International Journal of Environmental Research and Public Health, 14, 584.

Tirado Herrero, S., \& Urge-Vorsatz, D. (2012). Trapped in the heat: A postcommunist type of fuel poverty. Energy Policy, 49, 60-68. 
Tirado, S., \& Jiménez Meneses, L. (2016). Energy poverty, crisis and austerity in Spain. People, Place and Policy, 10, 42-56.

UNDP. (2004). Stuck in the past. Energy, environment and poverty in Serbia and Montenegro. Belgrade, Serbia/Montenegro: United Nations Development Programme/Country Office Serbia and Montenegro.

Velody, M., Cain, M. J. G., \& Philips, M. (2003). A regional review of social safety net approaches in support of energy sector reform. Washington, DC: US Agency for International Development.

World Bank. (1999a). Non-payment in the electricity sector in Eastern Europe and the former Soviet Union. Washington, DC: World Bank.

World Bank. (1999b). Privatization of the power and natural gas industries in Hungary and Kazakbstan. Washington, DC: World Bank.

World Health Organization Regional Office for Europe. (2007). Housing, energy and thermal comfort. A review of 10 countries within the WHO European region. Copenhagen: WHO Regional Office for Europe.

Open Access This chapter is distributed under the terms of the Creative Commons Attribution 4.0 International License (http://creativecommons.org/licenses/ by $/ 4.0 /$ ), which permits use, duplication, adaptation, distribution and reproduction in any medium or format, as long as you give appropriate credit to the original author(s) and the source, a link is provided to the Creative Commons license and any changes made are indicated.

The images or other third party material in this chapter are included in the work's Creative Commons license, unless indicated otherwise in the credit line; if such material is not included in the work's Creative Commons license and the respective action is not permitted by statutory regulation, users will need to obtain permission from the license holder to duplicate, adapt or reproduce the material.

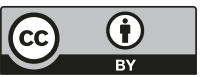

